\title{
SOCIAL PSYCHOLOGICAL CHARACTERISTICS OF TEACHER ACTIVITY IN INTEGRATION OF MOTHER TONGUE AND TEACHING LESSONS IN PRIMARY SCHOOLS
}

\section{Aziza Sh. Xusenova}

Lecturer Faculty Of Preschool And Primary Education Bukhara State University, Uzbekistan

\section{ABSTRACT}

The article discusses the activities of the teacher and its socio-psychological features in the integration of native language and reading lessons in primary school, the main tasks facing the teacher.

KEYWORDS: - Integration, modern school, psychological environment, teacher personality, pedagogical technique, education system, intellectual knowledge, motive, social consciousness, scientific potential.

\section{INTRODUCTION}

The role of the teacher and his responsibilities determine how important it is for society and the public to pay attention to the work of educating the younger generation. In the process of implementing the "National Training Program" in our country, the responsibility of teachers to society in educating and educating the younger generation will continue to grow.

In the current situation, the demands of society on the school are growing day by day, and the task of solving these requirements in practice depends on the teacher.

A modern school teacher performs a number of tasks. The teacher is the organizer of the learning process in the classroom. The teacher is one of the sources of knowledge for students to give the necessary advice during the lesson, in additional lessons, as well as outside the classroom. Many teachers act as class leaders and are the organizers of the educational process.

\section{THE MAIN FINDINGS AND RESULTS}

A modern teacher cannot be a social psychologist. Therefore, it is necessary to be able to establish interactions between students, to know the use of socio-psychological mechanisms in the children's community.

The teacher, as a member of the pedagogical 
CURRENT RESEARCH JOURNAL OF PEDAGOGICS 2(12): 140-142,

December 2021 DOI: https://doi.org/10.37547/pedagogics-crjp-02-12-28

ISSN 2767-3278

(C)2021 Master Journals

Crossref doi) 81 Google

Accepted 21 $1^{\text {th }}$ December, 2021 \& Published $26^{\text {th }}$ December, 2021

team of the school, is directly involved in the organization of school life, works in the methodological associations of various science teachers and class teachers, performs assignments. Every teacher is also a promoter of pedagogical knowledge as he or she reads and talks to students 'parents and the public.

It is known that pedagogical activity is one of the most complex areas of human labor.

The most important of the requirements set by the society is focused on the personality of the teacher and the qualities related to his profession.

The most important qualities of a teacher are:

- The teacher's devotion to his homeland, love for children, the desire to raise them in the spirit of humanity, love for their country, mother tongue, history and culture of their people, living in the idea of independence of the state;

- $\quad$ high sense of social responsibility;

- inculcate in children the highest goals of spirituality and enlightenment: nobility, intelligence, ingenuity, spiritual purity;

- self-control, patience, endurance, perseverance.

The main requirements of the society to the teacher are:

- $\quad$-knowledge of the essence of spiritual and enlightenment upbringing, the ideology of national awakening and universal wealth, upbringing children in the spirit of independence, loyalty to their ideas, love for their homeland, nature and family;

- have extensive knowledge, be aware of various knowledge:

- deep knowledge of youth pedagogical psychology, social psychology and pedagogy, youth physiology and school hygiene;

- have a solid knowledge of the subject he teaches, be aware of new achievements and shortcomings in world science in his profession;

- mastering the methods of education and upbringing;

- $\quad$-creative approach to their work;

- to know children, to understand their inner world;

- have pedagogical techniques (logic, speech, expressive means of teaching) and pedagogical tact;

- $\quad$-constantly improve their knowledge and pedagogical skills.

Every teacher should strive to be able to fully meet these requirements.

Parents expect the teacher to have the skills to raise and teach their children, regardless of their work experience and age.

It should be noted that along with the requirements to increase the effectiveness of the educational process, there are also growing social requirements for the teacher and his activities.

The requirements of the society to the teacher, different social expectations, the individuality of the teacher, his subjective readiness to meet the requirements, thus testify to the readiness of a particular teacher for pedagogical activity.

The teacher professiogram should include the specific requirements placed on the teacher by a particular subject. In order for a future teacher to know what requirements are set by this or that type of subject, and on this basis to organize the educational process, it is necessary to develop a professional profile of a teacher in a particular specialty in pedagogical universities.

Many years of research have shown that 
CURRENT RESEARCH JOURNAL OF PEDAGOGICS 2(12): 140-142,

December 2021 DOI: https://doi.org/10.37547/pedagogics-crjp-02-12-28

ISSN 2767-3278

(C)2021 Master Journals

Crossref dof 81 Google

Accepted 21 $1^{\text {th }}$ December, 2021 \& Published $26^{\text {th }}$ December, 2021

pedagogical skills consist of complex and multifaceted psychological knowledge. Using this research data, it is possible to identify a number of components (components) that play an important role in the structure of pedagogical skills.

In today's society, the independent acquisition of knowledge and professional development by a teacher - on the one hand, shows how successful teaching is, on the other hand, is an important task - because this urgent process saves a person from intellectual poverty.

From a psychological point of view, the teacher needs to be constantly engaged in improving their knowledge. Because this is the main feature of teaching work. While the educator is always among the people, he must, first of all, correctly explain the truth, which has long intrigued people, from his own point of view. Of course, such views in the teacher are formed in the process of many years of work and life activities; secondly, the teacher himself has a limited time available to students to obtain information: thirdly, he has the opportunity to communicate with his peers in a very narrow circle, often with limited professional interests.

The independent acquisition of knowledge by a teacher means that he is constantly updating his individual social experience on a large scale, constantly replenishing his knowledge with professional and cultural information.

Usually, most teachers use it successfully, realizing the need for independent learning.

Motives for this are usually formed as a result of understanding the problems facing the teacher in the process of pedagogical activity. In many cases, such motives are formed in the context of the desire to know how to teach and how to educate teachers, the recent achievements of science, the need to improve their pedagogical skills.
At the same time, we cannot turn a blind eye to some of the cases that are clearly visible. For example, a certain part of the teaching staff is in independent research, does not actively engage in improving their knowledge, does not seek to improve their skills, some are completely behind in development in certain areas of knowledge. Such teachers seriously harm the educational and upbringing development of the younger generation.

\section{Conclusion}

Independent knowledge and professional development of teachers is a necessary condition for increasing the effectiveness of pedagogical activities. Eastern thinkers have rightly said that a teacher can only become a teacher if he reads, and if he stops reading, then teaching will also die.

This fact should be well known to all teachers, regardless of age, pedagogical skills, what kind of teaching.

\section{REFERENCES}

1. National Training Program of the Republic of Uzbekistan. T- "Uzbekistan” 1997

2. Innovative pedagogical technologies in education and upbringing. R.Ishmukhamedov, R.Yuldashev - Tashkent "Nihol" 2014 y

3. Pedagogy of cooperation - Sh.Abdullaeva, R.Choriev - Tashkent 2016

4. Pedagogical conditions for the organization of the educational process focused on the personality of the student - B. Mamurov, Monograph - Tashkent 2014 